\title{
METODE ADAPTIVE NEURO FUZZY INFERENCE SYSTEM PADAAPLIKASI SISTEM CERDAS PENDUGAAN PRODUKSI GARAM
}

\section{ADAPTIVE NEURO FUZZYINFERENCE SYSTEM METHOD ONSMART APPLICATIONS ESTIMATING SALT PRODUCTION}

\author{
Pusat Riset Kelautan, \\ Badan Riset dan Sumber Daya Manusia Kelautan dan Perikanan \\ Kementerian Kelautan dan Perikanan \\ e-mail : d4n1.saepuloh@gmail.com
}

Dani Saepuloh, Muhammad Ramdhan, Rikha Bramawanto \& Sri Suryo Sukoraharjo

Diterima tanggal: 3 Juli 2019 ; diterima setelah perbaikan: 5 Agustus 2019 ; Disetujui tanggal: 31 Agustus 2019 DOI: http://dx.doi.org/10.15578/jkn.v14i2.7910

\begin{abstract}
ABSTRAK
Garam merupakan salah satu komoditas strategis, karena selain merupakan kebutuhan pokok manusia, garam juga digunakan sebagai bahan baku industri. Indonesia adalah salah satu negara yang memproduksi garam, namun Indonesia belum dapat memenuhi kebutuhan garam dalam negerinya sendiri. Kementerian Kelautan dan Perikanan (KKP) setiap tahun menargetkan produksi garam, dan sering kali target dan realisasi produksi garam tidak tercapai. Untuk meminimalkan resiko kerugian petambak garam dan bahan pertimbangan untuk menjaga neraca garam dibuatlah Sistem Cerdas Pendugaan Produksi garam dengan menggunakan metode Adaptive Neuro Fuzzy Inference System (ANFIS). Sistem kerja dalam penelitian ini dengan tiga variable: curah hujan, nino 34 dan dipole mode, dataset tersebut akan dibagi menjadi data training dan data testing. Data training digunakan sebagai prediktor sistem ANFIS sedangkan data testing digunakan untuk mengukur akurasi prediksi yang dihasilkan oleh ANFIS. Pengukuran tingkat akurasi menggunakan metode Root Means Square Error ( RMSE ) yang menunjukkan keakurasinya cukup baik mendekati nilai produksi garam.
\end{abstract}

Kata Kunci: Garam, sistem cerdas, produksi garam, ANFIS.

\section{ABSTRACT}

Salt is one of the strategic commodities, because besides being a basic human need, salt is also used as an industrial raw material. Indonesia is one of the countries that produce salt, but Indonesia has not been able to meet the needs of salt in its own country. The Ministry of Maritime Affairs and Fisheries (KKP) targets annual salt production, and often targets and realization of salt production is not achieved. Therefore, to minimize the risk of loss of salt farmers and considerations for maintaining salt balance, an Intelligent Estimation of Salt Production System was made using the Adaptive Neuro Fuzzy Inference System (ANFIS) method. The work system in this study with three variables: rainfall, nino 34 and dipole mode, the dataset will be divided into training data and testing data. Training data is used to be predictor in ANFIS systems while Testing data is used to measure the accuracy of predictions produced by ANFIS. Measurement of accuracy using the Root Means Square Error (RMSE) method which shows it's accuracy is quite good compared to the value of salt production.

Keywords: salt, intelegent system, salt production, ANFIS. 


\section{PENDAHULUAN}

Garam merupakan komoditas strategis, karena selain merupakan kebutuhan pokok manusia, garam juga digunakan sebagai bahan baku industri. Indonesia belum bisa memenuhi kebutuhan garam dalam negeri (Susanto et al., 2015), sehingga Indonesia melakukan impor (Jamil, 2015). Realisasi produksi garam seringkali meleset dari target yang ditetapkan (Gambar 1). Hal ini diduga karena penetapan target kurang memperhatikan perubahan cuaca/iklim musiman yang akan terjadi di tahun berikutnya. Sejak Tahun 2010, target produksi garam selalu ditingkatkan, namun realisasinya lebih banyak tidak tercapai. Produksi garam dapat melebihi target hanya terjadi pada 2012 dan 2015, masing - masing sebesar $157 \%$ dan $112 \%$. Kegagalan pencapaian target paling signifikan terjadi pada tahun 2010, 2013, 2016 dan 2017 yang masingmasing hanya sebesar 2,35\%,43,51\%,3,93\% dan $34,38 \%$. Hal ini disebabkan oleh kondisi cuaca dan tingginya curah hujan yang tidak mendukung untuk memproduksi garam (Aunurrofiqi, 2018).

Dalam rangka membantu memonitoring target dan realisasi produksi garam di Indonesia, dibutuhkan suatu teknologi tepat guna yang mampu memprediksi musim garam. Purwarupa Sistem Cerdas Pendugaan Produksi garam dengan menggunakan metode Adaptive Neuro Fuzzy Inference System (ANFIS) merupakan satu diantara pengembangan teknologi tepat guna dibidang kelautan dan perikanan untuk memonitoring hal tersebut.

Adaptive Neuro-Fuzzy Inference System (ANFIS) adalah penggabungan mekanisme Fuzzy Inference System yang digambarkan dalam arsitektur jaringan syaraf tiruan. (Dewi \& Hartatik, 2006). Metode ANFIS diharapkan bisa mengatasi ketidak konsistenan data yang didapat dari lapangan. Logika fuzzy mengevaluasi secara komprehensif, melalui analisis regresi dan multiple discriminan analisis methods, dan mencapai beberapa hasil, tapi indeks presisi dan metode evaluasi tidak tercapai dan sulit untuk menentukan bobot evaluasi (Dong \& Dai, 2009). Untuk mengoptimalkan kinerja fuzzy dalam penentuan bobot melalui pembelajaran, dapat digunakan metode hybrid yaitu penggabungan fuzzy dengan neural network (neuro fuzzy). ANFIS telah digunakan sebagai metoda pendugaan iklim (Buono et al., 2013) dan prediksi banjir (Prawiradisastra, 2017).

Parameter ANFIS dapat dipisahkan menjadi dua, yaitu parameter premis dan konsekuensi yang dapat diadaptasikan dengan pembelajaran hybrid, dilakukan dalam dua langkah yaitu langkah maju dan balik (Walid et al., 2014). Mekanisme penalaran terlihat pada Gambar 2.

Metode ANFIS merupakan implementasi dari sistem inferensi fuzzy dalam framework jaringan adaptif.

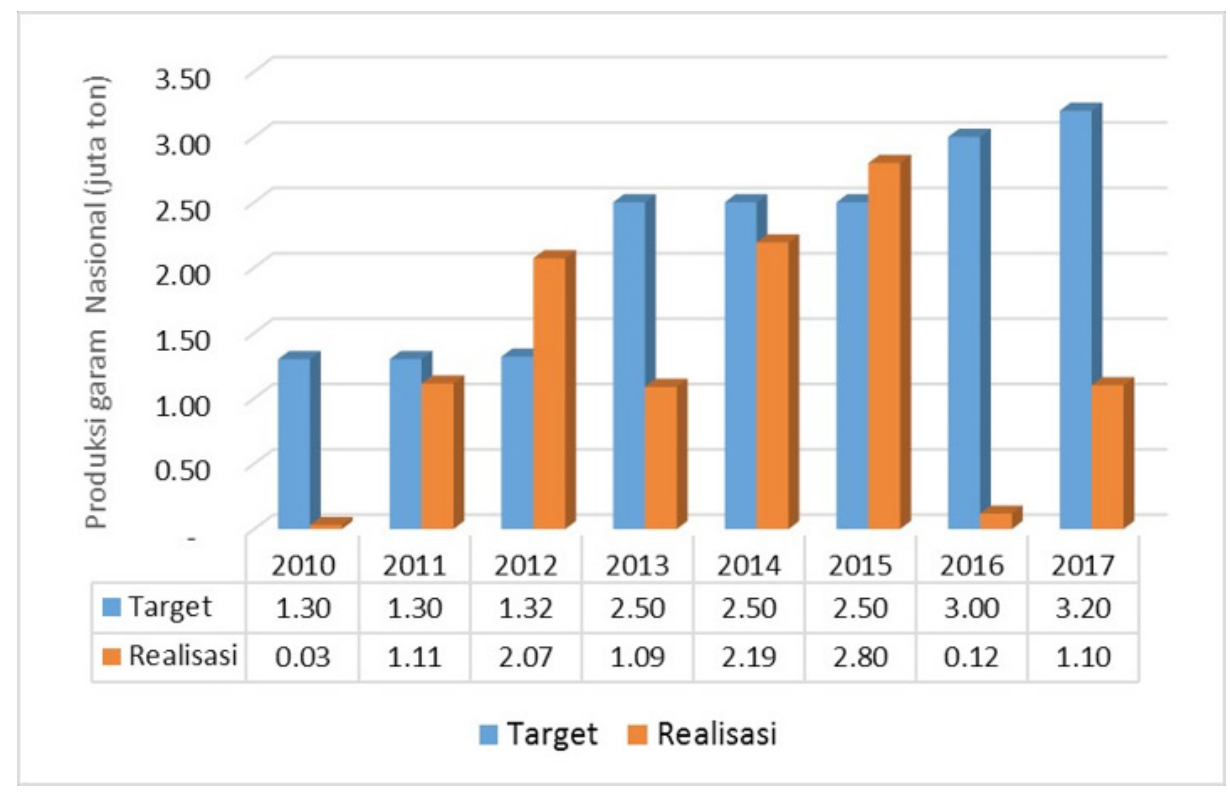

Gambar 1. Target dan Realisasi produksi garam 2010-2017.

(Sumber : Materi Rakor Swasembada Garam Nasional dan data Program Pugar KKP)

Figure 1. Target and Realization of salt production 2010-2017.

(Source: National Salt Self-Sufficiency Coordination Meeting material and KKP Fitter Program data)

JURNAL KELAUTAN NASIONAL, Vol. 14, No 2, Agustus 2019, Hal. 125-134 


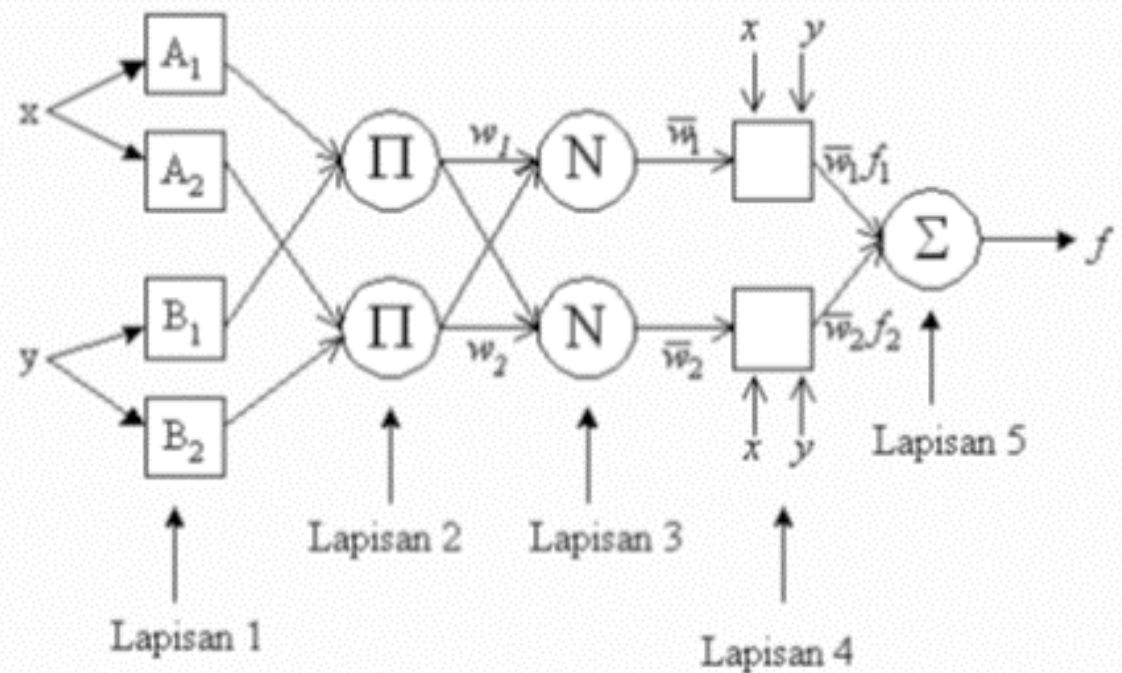

Gambar 2. Arsitektur ANFIS.

Figure 2. ANFIS Architecture.

Arsitektur ANFIS dapat digunakan mempekerjakan untuk model fungsi Non-Linear dan tidak teratur, serta dapat mengidentifikasi komponen Non-Linear dalam Sistem.Implementasi sistem inferensi fuzzy ini terdiri dari lima lapisan (Mathur et al., 2016) yaitu :

Lapisan 1 : Pada setiap simpul i pada lapisan ini adalah simpul adaptif dengan fungsisimpul.

$$
O_{1, i}=\mu A_{i}(x)
$$

Persamaan (1) menjelaskan bahwa $\mathrm{x}$ adalah masukan bagi simpul i, dan Ai adalah label bahasa (Linguistic Label) seperti misalnya "terang" atau "gelap", dll. Dengan kata lain, 01, adalahtingkatan keanggotaan dari himpunan fuzzy $\mathrm{Ai}$ dan menentukan derajad keanggotaan darimasukan $\mathrm{x}$ yang diberikan. Fungsi keanggotaan parameter dari A dapat didekati dengan fungsi Bell, Persamaan (2).

$$
\mu A(x)=\frac{1}{1+\left|\frac{x-l_{i}}{j_{i}}\right|^{2 k_{i}}}
$$

Di mana $\{j i, k, l i\}$ adalah himpunan parameter, parameter pada lapisan ini disebut parameter parameterp remis.

Lapisan 2 : Setiap simpul pada lapisan ini diberi label N (Gambar 2), pada Persamaan(3) bersifat non-adaptif (parameter tetap) yang mempunyai keluaran berupa perkalian dari semuasinyal yang masuk.

$$
O_{2, i}=w_{i}=\mu A(1) \times \mu A(2), i=1,2
$$

Persamaan (3) menyatakan bahwa masing-masing keluaran simpul menyatakan derajadpengaktifan dari aturan fuzzy. Secara umum beberapa operator T-Norm yang dapatmengungkapkan logika fuzzy AND dapat digunakan sebagai fungsi simpul pada lapisan ini.

Lapisan 3 : Setiap simpul pada lapisan ini diberi label N (Gambar 2), Persamaan (4) juga bersifat nonAdaptive. Masing-masing simpul menampilkan derajad pengaktifan ternormalisasi dengan bentuk.

$$
O_{3, i}=\bar{w}=\frac{w_{i}}{w_{1}+w_{2}}, i=1,2
$$

Lapisan 4 : Tiap simpul pada lapisan ini berupa simpul adaptif dengan fungsi simpul.

$$
O_{4, i}=\bar{w}_{i} f_{i}=\bar{w}_{i}\left(p_{i} x+q_{i} y+r_{i}\right)
$$

Persamaan (5) dengan $\bar{w} i$ adalah derajad pengaktifan ternormalisasi dari Persamaan (4) $\operatorname{dan}\{p i, q i, r\}$ merupakan himpunan parameter dari simpul ini. parameter di lapisan ini dinamakan parameterparameter konsekuen.

Lapisan lima : Simpul tunggal pada lapisan ini diberi label $\Sigma$ (Gambar 2), Persamaan (6) merupakan simpul tetap yang fungsinya untuk menjumlahkan semua 
masukan yang dihasil dariperhitungan pada Persamaan (5) :

$$
O_{s, i}=\sum_{i}^{-} w_{i} f_{i}=\frac{\sum w_{i} f_{i}}{\sum w_{i}}
$$

\section{Proses Pembelajaran ANFIS}

Satu tahap arah pembelajaran maju-mundur dinamakan satu epoch. Pembelajaran hibrid terdiri atas dua bagian yaitu arah maju (forward pass) dan arah mundur (backward pass).

\section{Pengujian Sistem}

Pengujian sistem dilakukan dengan cara membandingkan nilai prediksi yang dihasilkan oleh sistem yang dibangun (ANFIS) dengan data produksi garam di lapangan, adapun metode perbandingan yang digunakan adalah Root Means Square Error (RMSE), adapun persamaannya adalah sebagai berikut.

$$
\operatorname{RMSE}=\frac{1}{M N} \sqrt{\sum_{i=1}^{M} \sum_{j=1}^{N}\left(U_{i, j}-V_{i, j}\right)^{2}}
$$

Data curah hujan diperlukan karena produksi garam sangatlah tergantung pada cuaca. Produksi garam di Indonesia masih banyak yang menggunakan cara tradisional yang tergantung pada pemanasan sinar matahari. Jika curah hujan berlangsung lama, ditunjukkan dengan angka rata-rata tahunan yang besar maka produksi garam cenderung akan turun.

El Nino-Southern Oscillation (ENSO) merupakan salah satu bentuk penyimpangan iklim di Samudera Pasifik yang ditandai dengan kenaikan suhu permukaan laut di daerah khatulistiwa bagian tengah dan timur. Fenomena ENSO memiliki 3 fase, yaitu fase El Nino, normal dan La Nina. Peningkatan suhu permukaan laut atau Sea Surface Temperature dari kondisi normalnya akan menyebabkan El Nino, sedangkan penurunan Sea Surface Temperature dari kondisi normalnya akan menyebabkan La Nina. Intensitas El Nino dan La Nina berbeda-beda tergantung anomali suhu permukaan laut yang terjadi. El Nino lemah terjadi ketika anomali suhu permukaan laut berkisar antara $0,5^{\circ} \mathrm{C}-1{ }^{\circ} \mathrm{C}$, El Nino sedang saat anomali SST berkisar $1,1^{\circ} \mathrm{C}-1,5^{\circ} \mathrm{C}$ dan kategori El Nino kuat ketika anomali SST lebih dari atau sama dengan $1,5^{\circ} \mathrm{C}$ selama tiga bulan berturutturut (Fajri, 2018).

Perubahan El Nino bisa menyebabkan curah hujan di sebagian besar di indonesia semakin berkurang. Tingkat berkurangnya curah hujan ini tergantung dari tingkat El Nino tersebut. ElNino juga bisa menyebabkan kekeringan panjang di indonesia sehingga memberikan dampak buruk seperti kebakaran hutan, efek rumah kaca, dan asap- asap yang beredar dimana-mana.

Peristiwa Dipole Mode ditandai dengan adanya perbedaan anomali suhu permukaan laut antara amudera hindia tropis bagian barat dengan samudera hindia bagian timur. Anomali ini memiliki kondisi yang sangat dingin lebih dingin dari cuaca normal. Dipole mode merupakan gelombang kuasi dua tahunan yang menyumbang sebagian besar variabilitas musim antar-tahunan di Samudera Hindia Selatan (Menezes \& Vianna, 2019). Tujuan penulisan artikel ini untuk memperkirakan produksi garam pertahun dengan menggunakan metode ANFIS.

\section{BAHAN DAN METODE}

Sistem kerja dalam purwarupa disusun dengan mengolah tiga variabel, yaitu: curah hujan, nino 34 dan dipole mode yang membentuk suatu dataset. Dataset tersebut akan dibagi menjadi data training dan data testing. Data training digunakan untuk melatih sistem ANFIS sedangkan data testing digunakan untuk mengukur akurasi prediksi yang dihasilkan oleh ANFIS. Sebagai pengukur tingkat akurasi sistem, digunakan metode Root Means Square Error ( RMSE ).

Data yang digunakan berupa data Produksi garam, curah hujan, dan data dipole mode selama rentang waktu 29 Tahun dari Tahun 1990 - 2018 dapat dilihat pada Tabel 3.

\section{Proses Pengolahan Data}

Tahapan proses pengolah data dapat dilihat pada Gambar 3. Langkah-langkah dari proses ini dijelaskan sebagai berikut:

1. Input sistem menggunakan data produksi garam PT. Garam dari tahun 1990 sampai tahun 2017, Pembagian kelompok variabel Curah hujan dibagi kedalam 4 kategori dapat di lihat di Tabel 1

2. Implementasi ANFIS untuk prediksi prduksi garam dengan 3 variabel yaitu: curah hujan, nino 34 dan dipole mode. Sistem prediksi garam ini memiliki beberapa tahapan dan langkah-langkah sebagai berikut: a. Tahap pertama adalah meng-inputkan data curah hujan, nino 34, dipole mode dan produksi garam produksi garam.

b. Tahap selanjutnya adalah melakukan pelatihan dengan menggunakan algoritma pembelajaran ANFIS. Pada tahap ini data diambil secara acak data testing 


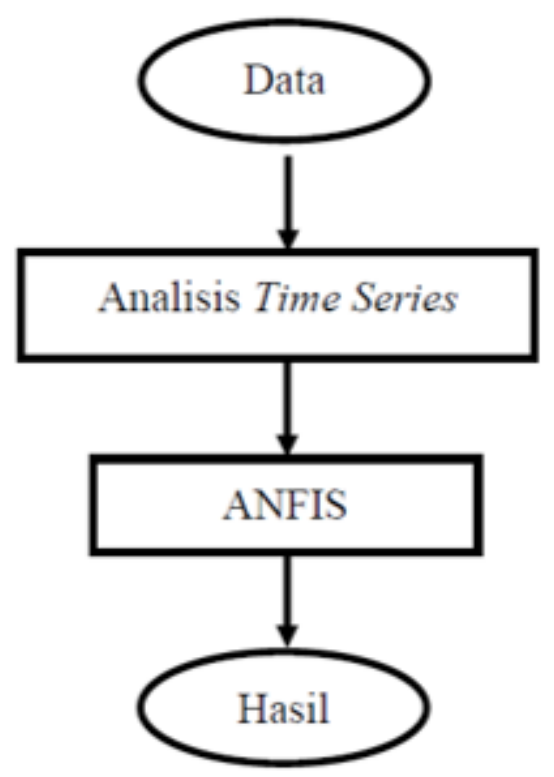

Gambar 3. Arsitektur ANFIS.

Figure 3. ANFIS Architecture.

Tabel 1. Curah hujan (sumber: BMKG)

Table 1. Rainfall (source: $B M K G$ )

\begin{tabular}{ll}
\hline Curah Hujan (mm) & Curah Hujan (mm) \\
\hline $0-20$ & Rendah \\
$20-50$ & \\
$50-100$ & \\
\hline $100-150$ & Menengah \\
$150-200$ & \\
$200-300$ & Tinggi \\
$300-400$ & \\
\hline $00-500$ & Sangat tinggi \\
\hline
\end{tabular}

melalui 5 layer.

c. Setelah dilakukan pelatihan dan didapatkan kondisi jaringan yang optimal, dilakukan pengujian dengan menggunakan nilai parameter jaringan dari hasil pelatihan.

d. Menampilkan keluaran akhir dari perhitungan ANFIS berupa pendugaan produksi garam.

MATLAB (Matrix Laboratory) digunakan dalam pembangunan sistem cerdas pendugaan produksi garam. MATLAB merupakan bahasa pemrograman tingkat tinggi berbasis pada matriks, MATLAB sering digunakan pada, 1) Matematika dan komputansi, 2) Pengembangan dan algoritma, 3) emrograman modeling, simulasi, dan pembuatan prototipe, 3) Analisa data, eksplorasi dan visualisasi, 4) Analisis numerik dan statistik,5) Pengembangan aplikasi teknik.

\section{HASIL DAN PEMBAHASAN}

Pendugaan produksi garam dihitung dari data curah hujan, nino 34, dipole mode dan produksi garam, untuk data training dapat dilihat dalam Tabel 2, Metode ANFIS membutuhkan proses pembelajaran atau learning agar bisa menghasilkan keputusan.

\section{Fuzzyfikasi Parameter}

Fuzzyfikasi parameter yang dilakukan pada penelitian ini berdasarkan bentuk model fungsi keanggotaannya, sebagai berikut:

a. Load data training dengan anfis dapat dilihat pada Gambar 4

b. Generate Fis dengan number of MFs 4 untuk curah hujan 8 untuk nino dan 3 untuk dipole mode, 
Tabel 2. Tabel produksi garam dari tahun 1991 sampai tahun 2017

(sumber: curah hujan dari BMKG, Nino dan dipole mode dari NOAA)

Table 2. Table of salt production from 1991 to 2017

(source: rainfall from $B M K G$, Nino and dipole mode from NOAA)

\begin{tabular}{|c|c|c|c|c|}
\hline Tahun & $\begin{array}{l}\text { Curah Hujan } \\
(\mathrm{mm})\end{array}$ & Nino & Dipole Mode & $\begin{array}{l}\text { Produksi Garam } \\
\text { (ton) }\end{array}$ \\
\hline 1990 & 86,30 & 0,11 & 0,00 & 268.579 \\
\hline 1991 & 92,80 & 0,66 & 0,41 & 300.040 \\
\hline 1992 & 247,15 & 0,00 & $-0,35$ & 216.844 \\
\hline 1993 & 258,15 & 0,34 & 0,13 & 294.200 \\
\hline 1994 & 14,00 & 0,57 & 0,85 & 393.725 \\
\hline 1995 & 253,65 & $-0,39$ & 0,11 & 247.364 \\
\hline 1996 & 221,75 & $-0,25$ & $-0,41$ & 249.012 \\
\hline 1997 & 50,25 & 1,92 & 0,98 & 321.767 \\
\hline 1998 & 512,70 & $-0,87$ & $-0,13$ & 40.043 \\
\hline 1999 & 369,80 & $-1,01$ & 0,25 & 136.705 \\
\hline 2000 & 509,70 & $-0,56$ & 0,25 & 62.128 \\
\hline 2001 & 458,20 & $-0,17$ & 0,10 & 93.110 \\
\hline 2002 & 278,85 & 0,89 & 0,33 & 238.230 \\
\hline 2003 & 238,35 & 0,17 & 0,29 & 266.003 \\
\hline 2004 & 134,80 & 0,54 & 0,12 & 307.632 \\
\hline 2005 & 219,90 & $-0,08$ & $-0,05$ & 254.658 \\
\hline 2006 & 21,80 & 0,48 & 0,59 & 316.186 \\
\hline 2007 & 218,65 & $-0,85$ & 0,41 & 212.066 \\
\hline 2008 & 244,85 & $-0,25$ & 0,40 & 250.128 \\
\hline 2009 & 128,25 & 0,82 & 0,24 & 308.572 \\
\hline 2010 & 519,70 & $-1,27$ & 0,08 & 4.497 \\
\hline 2011 & 228,15 & $-0,65$ & 0,56 & 156.712 \\
\hline 2012 & 107,75 & 0,37 & 0,58 & 307.348 \\
\hline 2013 & 376,15 & $-0,21$ & 0,11 & 156.826 \\
\hline 2014 & 89,10 & 0,42 & 0,18 & 336.763 \\
\hline 2015 & 39,60 & 1,92 & 0,67 & 340.335 \\
\hline 2016 & 594,30 & $-0,42$ & $-0,16$ & 25.500 \\
\hline 2017 & 365,60 & $-0,28$ & 0,58 & 194.300 \\
\hline 2018 & 108,00 & 0,40 & 0,20 & 308.36 \\
\hline
\end{tabular}

Dipilih error tolerance sebesar 0 (default). Kemudian banyaknya epoch (iterasi) proses training ditentukan sebanyak 100, Training error grafiknya semakin menurun dan mencapai titik error tetap pada angka 1,3406 pada saat epoch mencapai 100 . Artinya bahwa proses training menghasilkan error minimum pada nilai 1,3406 terdapat pada Gambar 5 .

c. Fuzzy logic dari sistem pendugaan produksi garam dengan 3 input dan 1 output, dapat dilihat pada gambar 6.

d. Tampilan antar muka/User Grafical Interface (GUI) sistem pendugaan produksi garam dapat dilihat pada Gambar 7.

Penggunaan tampilan GUI seperti pada gambar 6 . Sangatlah sederhana. User dapat mengisi data curah hujan dalam satuan $\mathrm{mm} /$ tahun dalam baris pertama GUI, kemudian data indeks El-nino pada tahun tersebut di baris kedua, dan data Dipole mode pada tahun yang sama di baris kedua. Hasil prediksi produksi garam dalam satuan Ton akan tampil secara otomatis di baris terakhir GUI. Hasil uji menggunanakan GUI dengan menggunakan data 10 tahun dari 2008 sampai 2018 dapat di lihat pada Tabel 3. Pada Tabel 3, memperlihatkan perbandingan produksi garam dengan hasil prediksi ANFIS relatif sama. Hal ini menunjukkan metode adaptive neuro fuzzy inference system dapat digunakan untuk menduga produksi garam.

\section{KESIMPULAN DAN SARAN}

Penerapan metode Adaptive Neuro Fuzzy Inference System (ANFIS) untuk sistem cerdas pendugaan produksi garam memiliki nilai akurasi secara keseluruhan mendekati nilai produksi garam. Purwarupa sistem cerdas pendugaan produksi garam 


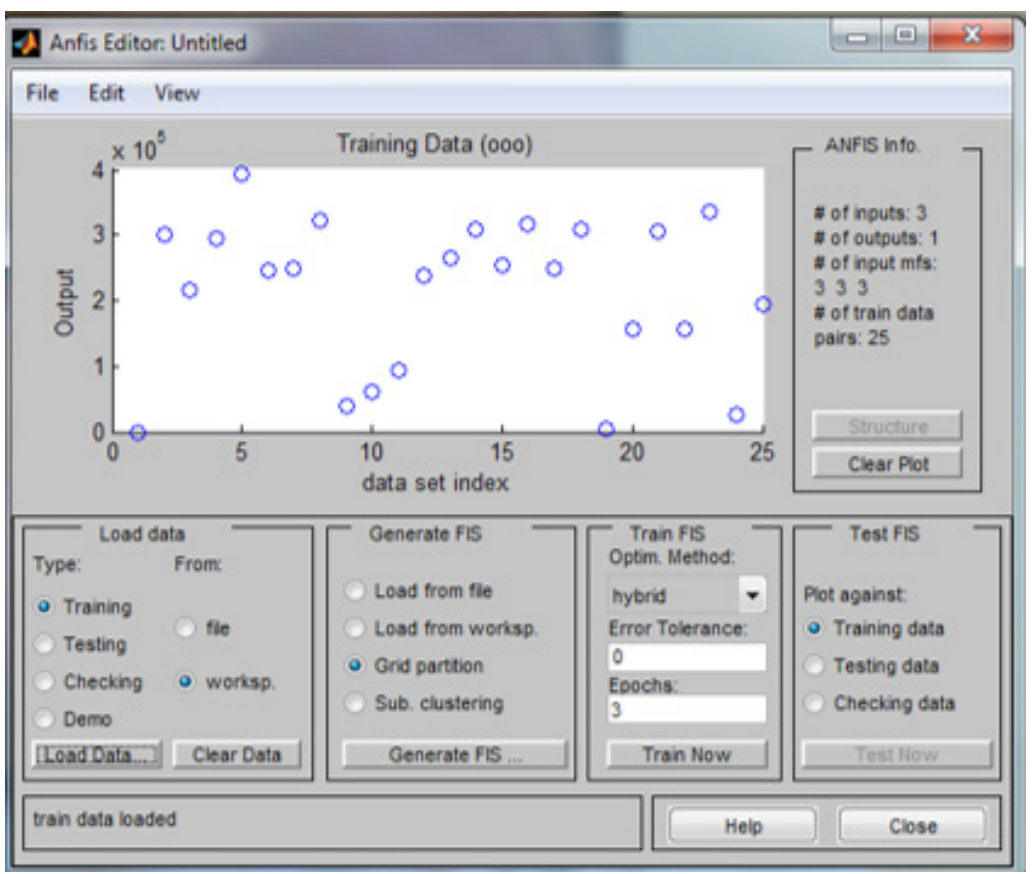

Gambar 4. Load data training untuk pendugaan produksi garam. Figure 4. Load training data for estimating salt production.

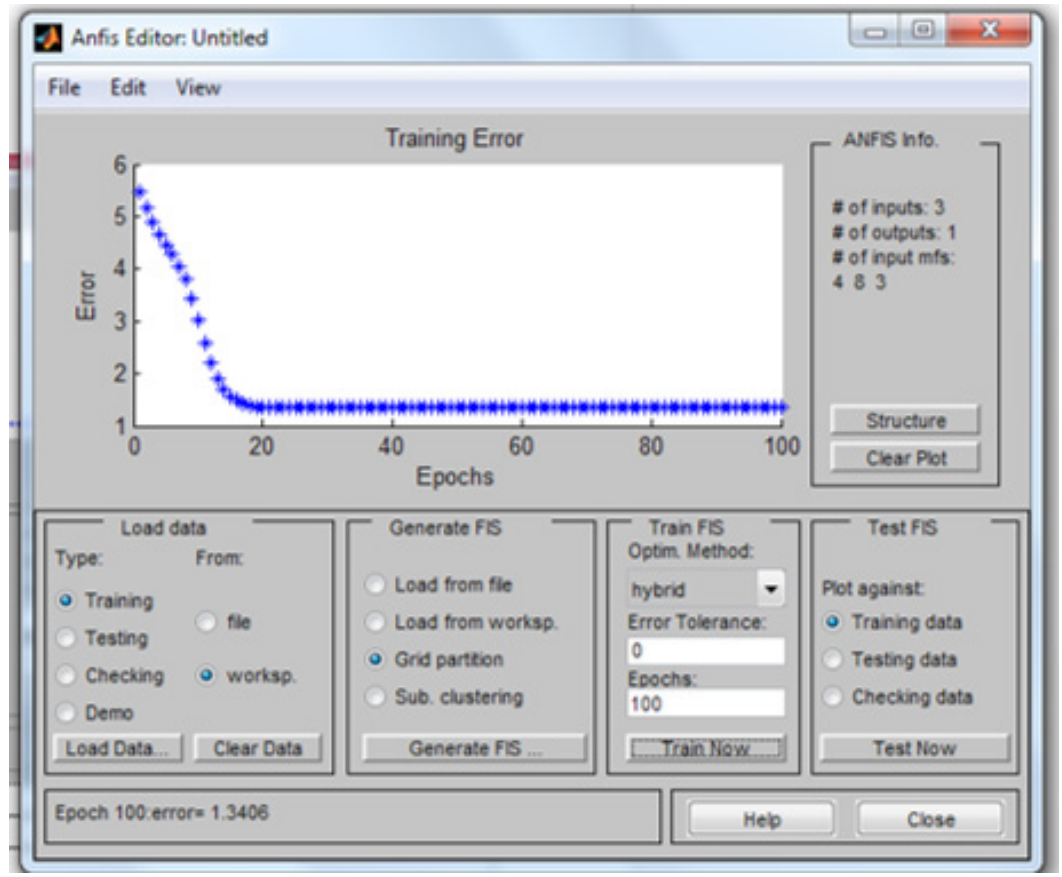

Gambar 5. Pengukuran error antara training data menggunakan RMSE.

Figure 5. Measurement of errors between training data uses RMSE. 


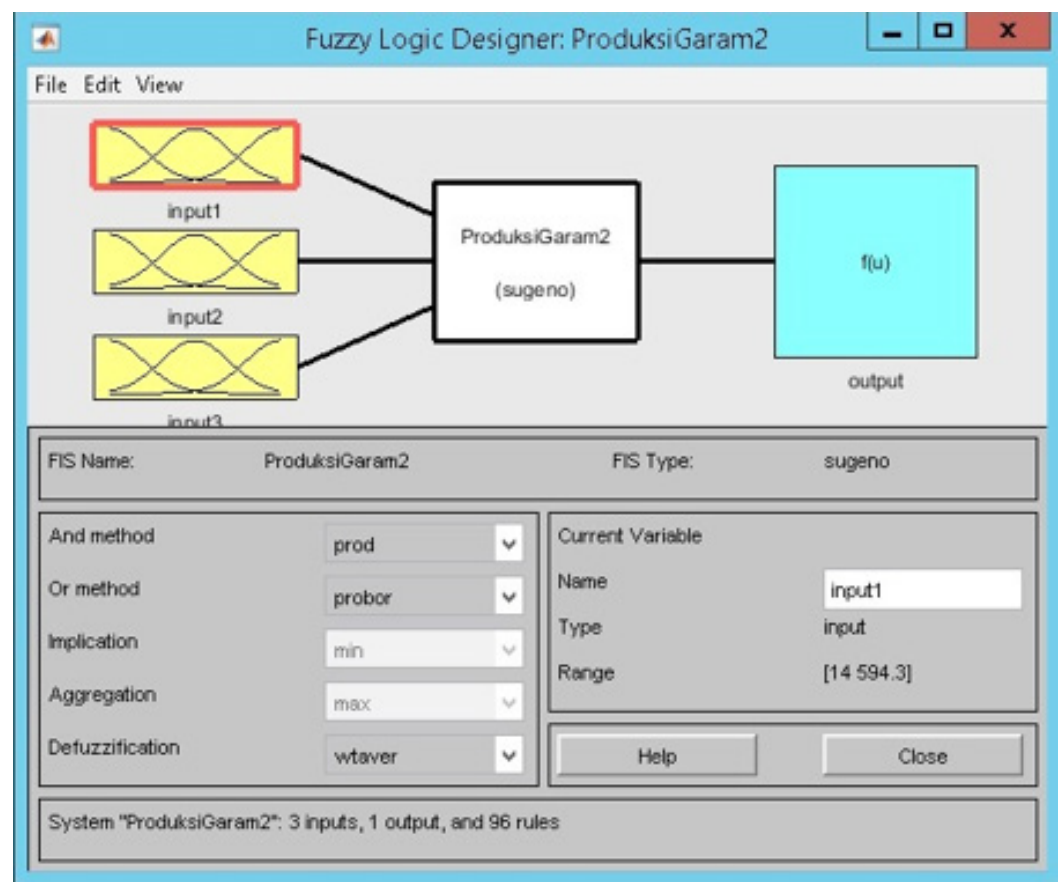

Tabel 6. Data Uji Sistem Pendugaan Produksi Garam Table 6. Salt Production Estimation System Test Data

Gambar 6. Fuzzy logic dari sistem pendugaan produksi garam.

Figure 6. Fuzzy logic of the salt production estimation system.

\begin{tabular}{llllll}
\hline Tahun & Curah Hujan & Nino & Dipole Mode & \multicolumn{2}{c}{ Produksi GaramHasil Prediksi ANFIS } \\
\hline 2008 & 244,85 & $-0,25$ & 0,40 & 250.128 & 250.129 \\
2009 & 128,25 & 0,82 & 0,24 & 308.572 & 308,57 \\
2010 & 519,70 & $-1,27$ & 0,08 & 4.497 & 4,49703 \\
2011 & 228,15 & $-0,65$ & 0,56 & 156.712 & 156.713 \\
2012 & 107,75 & 0,37 & 0,58 & 307.348 & 307.347 \\
2013 & 376,15 & $-0,21$ & 0,11 & 156.826 & 156.826 \\
2014 & 89,10 & 0,42 & 0,18 & 336.763 & 336.759 \\
2015 & 39,60 & 1,92 & 0,67 & 340.335 & 340.334 \\
2016 & 594,30 & $-0,42$ & $-0,16$ & 25.500 & 25,4999 \\
2017 & 365,60 & $-0,28$ & 0,58 & 194.300 & 194.299 \\
2018 & 108,00 & 0,40 & 0,20 & 308,36 & 353.921 \\
\hline
\end{tabular}

dengan Grafikal User Interface (GUI) masih dalam tahap awal pengembangan namun secara umum sangat mudah dalam pengaplikasiannya.

\section{UCAPAN TERIMA KASIH}

Ucapan terima kasih penulis sampaikan kepada Pusat Riset Kelautan dengan kegiatan riset Disain Sistem Produksi Sentra Garam Tahun Anggaran 2019. Kepada editor dan reviewer Jurnal Kelautan Nasional, diucapkan terima kasih telah menjadikan artikel ini menjadi layak terbit.

\section{DAFTAR PUSTAKA}

Anonim, (2015), Materi Rakor Swasembada Garam Nasional, 9 April 2015, Kementerian Kelautan dan Perikanan, Jakarta.

Aunurrofiqi, I, (2018), Hubungan Karakteristik Kewirausahaan Petani Garam Dengan Keberhasilan Usaha Garam Di Kabupaten Rembang, Skripsi, Departemen Agribisnis Fakultas Ekonomi Dan Manajemen, Institut Pertanian Bogor, Bogor. 


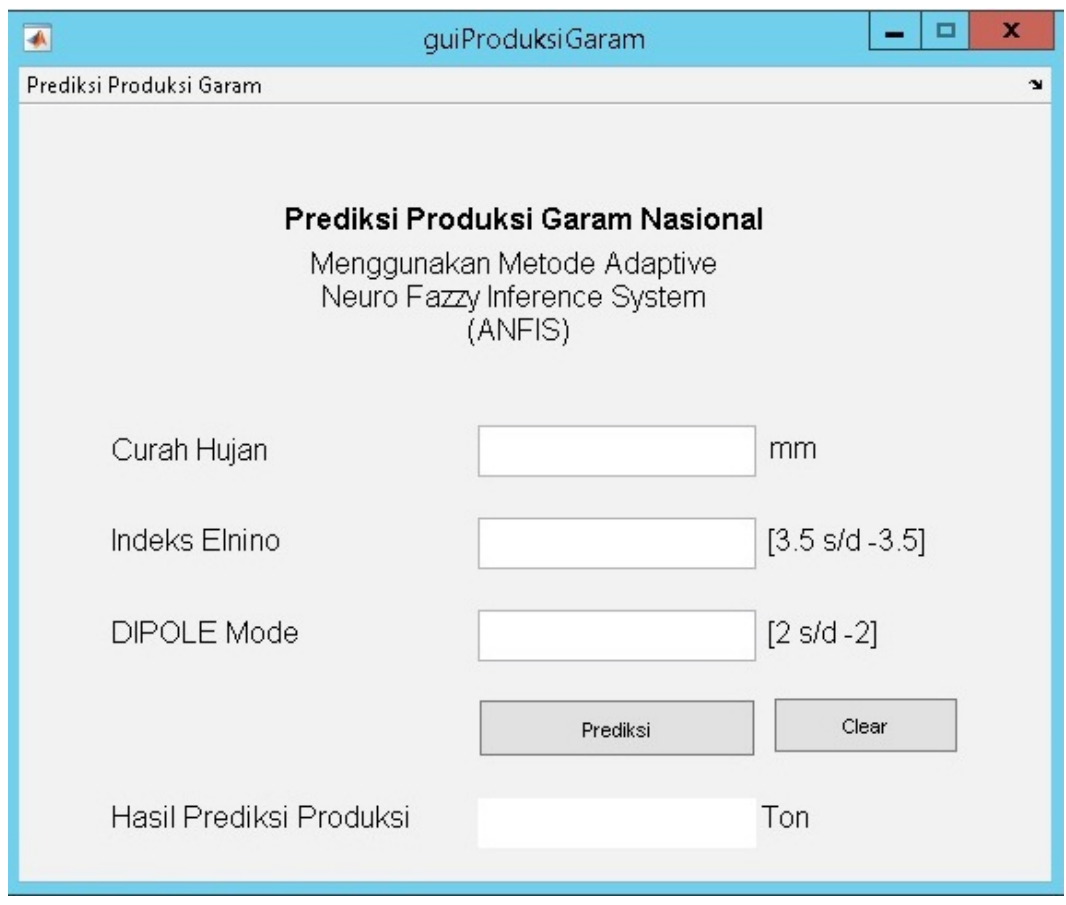

Gambar 7. Tampilan antar muka dari sistem pendugaan produksi garam. Figure 7. Display interface of the system for estimating salt production.

Buono, A., Budiman, J., \& Musthofa. (2013). Prediksi Awal Musim Hujan Menggunakan Adaptive Neuro Fuzzy Inference System Pada Studi Kasus Kabupaten Indramayu, Himpunan Informatika Pertanian Indonesia (HIPI), Bogor.

Dewi, S. dewi, \& Hartatik, S. (2006). Neuro Fuzzy integrasi Sistem Fuzzy dan Jaringan Syaraf Tiruan. Jojakarta: Graha Ilmu.

Dong, P., \& Dai, F. (2009). Evaluation for Teaching Quality Based on Fuzzy Neural Network. 2009 First International Workshop on Education Technology and Computer Science. Zhengzhou: IEEE Computer Society.

Fajri, H. C. (2018). Kaitan Perubahan Iklim Terhadap Harga Pangan Serta Hortikultura Di Daerah Terdampak Fenomena El Nino Dan La Nina. Skripsi, Departemen Ilmu Ekonomi, Fakultas Ekonomi Dan Manajemen, Institut Pertanian Bogor, Bogor .

https://www.bmkg.go.id/iklim/informasi-hujan-bulanan. bmkg? $\mathrm{p}=$ analisis-curah-hujan-dan-sifat-hujanbulan-juni-2017\&lang=ID di akses pada tanggal 5 februari 2019

https://ilmugeografi.com/ilmu-bumi/iklim/iklim-diindonesiadi akses pada tanggal 12April 2019

Jamil, A. S. (2015). Analisis Permintaan Impor Garam Indonesia. Tesis, Program Pascasarjana Ilmu Ekonomi Pertanian, Institut Pertanian Bogor, Bogor.

Mathur, N., Glesk, I., \& Buis, A. (2016). Comparison of adaptive neuro-fuzzy inference system (ANFIS ) and Gaussian processes for machine learning ( GPML ) algorithms for the prediction of skin temperature in lower limb prostheses. Medical Engineering and
Physics, 38(10), 1083-1089. https://doi.org/10.1016/j. medengphy.2016.07.003

Menezes, V. V. \& Vianna, M. L. (2019). Quasi-biennial Rossby and Kelvin waves in the South Indian Ocean: Tropical and subtropical modes and the Indian Ocean Dipole, Deep Sea Research Part II: Topical Studies in Oceanography, In Press, Corrected Proof, https://doi. org/10.1016/ j.dsr2.2019.05.002

Prawiradisastra, F, (2017), Pengembangan Model Prediksi Banjir Menggunakan Adaptive Neuro Fuzzy Inference System (Anfis) Pada Sungai Ciliwung, Tesis, Program Sekolah Pascasarjana, Institut Pertanian Bogor, Bogor.

Susanto, H., Rokhati, N., \& Santosa, G. W. (2015), Development of Traditional Salt Production Process for Improving Product Quantity and Quality in Jepara District, Central Java, Indonesia, Procedia Environmental Sciences 23, Pp 175-178. https:// doi: 10.1016/j.proenv.2015.01.027

Walid, M., Suprapto, Y. K., \& Zaini, A. (2014). Noise Detection On The Temple Relief Images Using Adaptive Neuro Fuzzy Inference System. ISITIA 2014 
